\title{
教育講演
}

\section{4. びまん性汎細気管支炎とエリスロマイシン療法}

\section{工藤 翔二}

Key words：びまん性汎細気管支炎, エリスロマイシン療法, マクロライド

はじめに

びまん性沉細気管支炎diffuse panbronchiolitis（以下, DPB）は, 疾患の難治性のみなら ず，その疾患概念と治療法がわが国において確 立したことから，日本の呼吸器病学における近 年の歴史の中で重要な位置を占める欵患であ る。本疾患の予後は，エリスロマイシンをはじ めとする14員環マクロライドによる特異な治療 法であるEM療法の発見と確立によって画期的 に改善した。さらに，EM療法の作用機序に関 する研究を通じて，気道炎症の病態の解明が進 むとともに，マクロライドの新作用ともいうべ き抗菌活性以外の多くの作用が見いだされ，新 たな臨床応用と創薬への期待が高まっている。

\section{DPBの疾患概念と世界分布}

呼吸細気管支に病変の主座をおくDPBの疾 患概念は，1969年，本間，山中らによって提唱 され，それに続く多くの臨床病理学的研究に よって発展，確立された．その概要は第83回の 本学会 (1986年)において，本間日臣教授によっ て宿題報告 ${ }^{1}$ がなされている，呼吸器疾患とし てのDPBは以下の6つに特徵づけることがで

くどうしょうじ：日本医科大学第四内科
きる，第 1 に形態と病変の場，およびそれを反 映する画像表現からみた「びまん性肺疾患」, 第 2 に呼吸機能面からみた「閉塞性肺疾患」, 第 3 に治療と予後を左右する「慢性気道感染 症」, 第 4 に寒冷凝集素価の持続高值にみられ る「免疫学的関連疾患」, 第 5 に高率な慢性副 鼻腔炎の合併に示される「副鼻腔気管支症候 群」，そして，第 6 にHLA抗原との関連に示さ れる遺伝性要因が関与する人種依存性の「多因 子疾患」であることである.

DPBの臨床診断基準は, 1980年に厚生省研 究班によって初めて作られたが，その後の研究 成果をふまえて，1995年に第 1 次改訂が，98年 に第 2 次改訂 ${ }^{2 !}$ (表) が行われた。ここでは, 咳・痰，息切れの症状に加えて，慢性副鼻腔炎 を既往ないし合併するという副鼻腔気管支症候 群であることを前提としここれに胸部X線上の びまん性粒状影ないしCT上の小葉中心性粒状 影を認めた場合に本疾患を疑い，さらに呼吸機 能上の開塞性換気障害と低酸素血症，寒冷凝集 素価の高値, 聴診上の水泡性ラ音を補助項目と して扱っている.

DPBという疾患名が欧米誌に初めて登場し たのは，わが国における疾患概念提唱から14年 を経た1983年のことであり ${ }^{3)}$ この長い間隙は 本疾患が欧米には稀であるという人種依存性を めぐる問題と無関係ではない，現在では，Freser\&ParéやCherniackの教科書など欧米の標準 
表. DPB の臨床診断基準 (第 2 次改訂)

\section{1. 診断項目 \\ 1）必須項目 \\ (1)持続性の咳・痰，および労作時息切れ \\ (2)慢性副番腔炎の合併ないし既往 \\ (3)胸部 X 線で両肺野びまん性散布性粒状影，または 胸部 CT で両肺野びまん性小葉中心性粒状病変 \\ 2) 参考項目 \\ (1)胸部聴診で断続性ラ音 \\ (2) 1 秒率低下 $(70 \%$ 以下) および低酸素血症 (80Torr 以 下) \\ (3)寒冷凝集菜価高值 (64 倍以上) \\ 2. 臨床診断 \\ 確実必須項目(1), (2), (3)に加え, 参考項 目の 2 項目以上を満たすもの \\ ほほ確実＼cjkstart必須項目(1)，(2)，(3)を満たすもの 可能性あり 必須項目のうち(1)，(2)を満たすもの \\ 3. 鑑別診断 \\ 慢性気管支炎, 気管支拡張症, 線毛不動症候群, 閉塞性細気管支炎，麗胞性線維症などである。病 理組織学的検查は本症の確定診断上有用である.}

的教科書にも疾患項目として掲載される国際的 に認知された疾患となっている。しかし，図 1 に示すように欧米からの今日までの報告例は18 症例ときわめて少なく（1998年末現在）, しか もその半数（9例）はアジア系人種である。一 方，東アジア諸国では日本（10万対11.0）を筆
頭に, 韓国, 中国, 台湾, 香港にも数多くみら れることが, 最近の国際研究交流出から明らか になった。最近の日韓両国人およびDPB患者 のHLAハプロタイプの検討占6) では, 第 6 染色 体HLA-A，B遺伝子間にDPB疾患感受性遺伝子 が存在する可能性が示唆され，両遗伝子間のマ イクロサテライト解析によってHLA-A， B間に 疾患感受性遺伝子座に近接すると考えられる マーカーが認められている。このように, DPB はCaucasianにおけるcystic fibrosisに対応した 東アジア系人種（Mongoloid）に特有な多因子 疾患とみなされ，その疾患感受性遺伝子の解明 が重要な課題となっている.

\section{EM療法の発見と予後の改善}

厚生省研究班（1982年）によるEM療法以前 のDPBの予後》は, 初診時からの 5 年生存率で $42 \%$ あった。気道感染菌は, 初診時に $44 \%$ あったインフルエンザ菌が最終観察時には $16 \%$ に減少する一方, 緑膿菌が $22 \%$ か $60 \%$ に増加 している. そして, 緑膿菌感染以後の 5 年生存 率はわずか $8 \%$ と劣悪なものであった. DPB における進行性の呼吸困難と予後の不良さが,

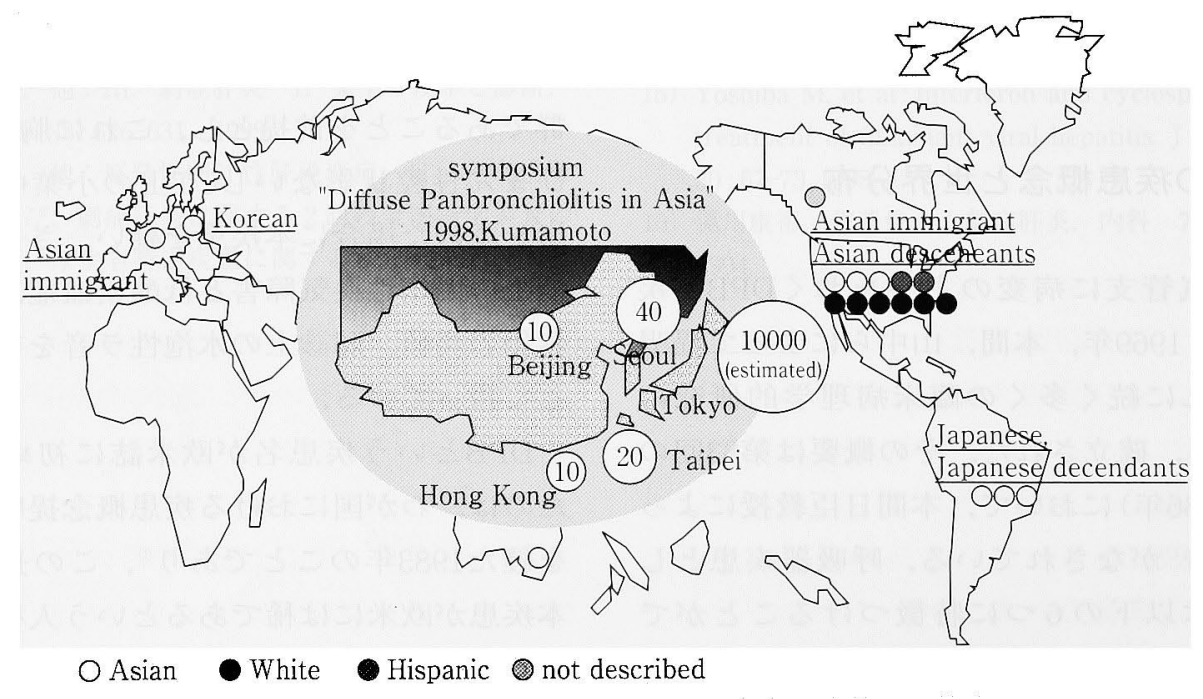

図 1. DPBの世界分布（1998） 


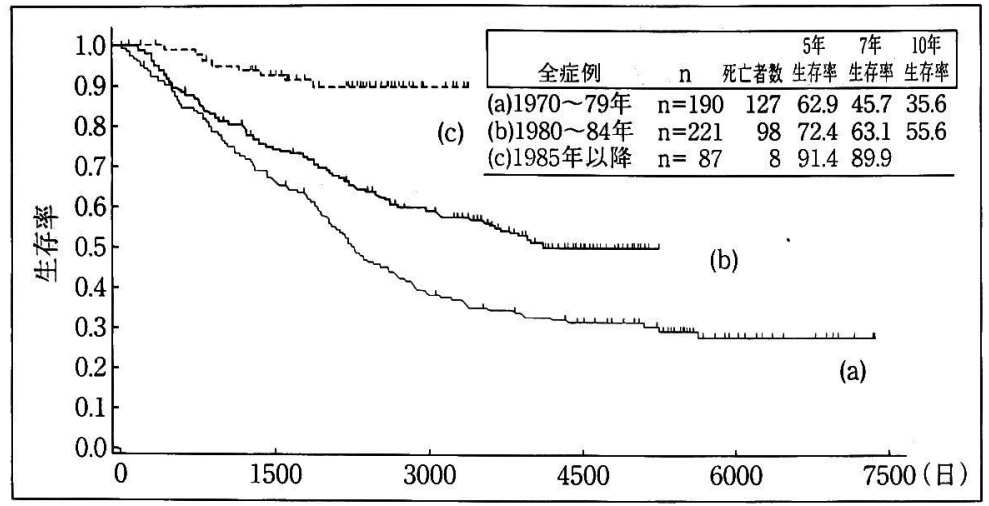

図 2. 初診年度別生存曲線（厚生省研究班，1998）(文献12より)

薬の選択 エリスロマイシン $400-600 \mathrm{mg} /$ 日 副作用(胃腸障害)、薬の相互作用のあるものは クラリスロマイシン、ロキシスロマイシン

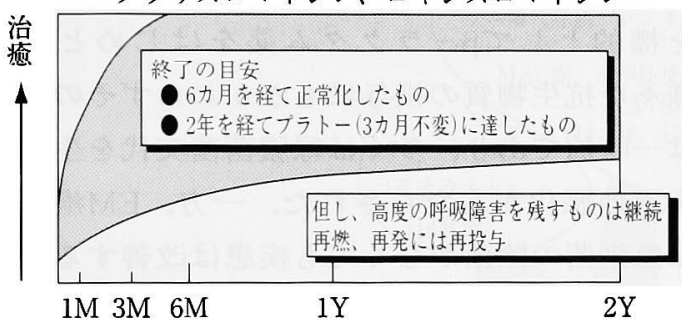

図 3. DPBに対するマイクロライド療法 厚生省研究班 (1998)

患者と医師をいかに苦しめていたかは, 1978年， 谷本 ${ }^{81}$ によって報告されたDPB剖検例15例のう ち, 1 例が自殺, 2 例が自殺未遂後の呼吸不全 悪化によるものであったという事実からも窥い 知ることができる。

EM療法の発端症例（54藏男性） ${ }^{99}$ は, 開胸 肺生検によってDPBの組織診断が得られ，ス テロイドや各種抗生物質による治療にもかかわ らず悪化し， 2 年間の中断の後，再び我々のも とに登場したときには，自覚症状はほとんどな く, 胸部X線所見は正常化し, $\mathrm{PaO} 2$ は55Torr から85Torrに改善していた。患者はこの間， 松本市の開業医, 故宮沢博医師のもとに通院し ており，その処方内容の一つがEM600mgで あった. 宮沢医師は新潟大学卒業後, 薬理学教 室で研究従事されたが, 同じ時期に内科には「テ
トラサクリン微量療法」を提唱され, わが国で 初めて抗生物質の抗菌作用以外の生物活性に注 目された桂重鴻教授が在任されていた. 筆者は, このお二人に今日のEM療法ないし14員環マク ロライド療法のルーツを見出したい.

本症例を契機として，DPBに対するEM少量 長期療法の試みが開始された。個別施設におけ る臨床検討のほか, レトロスペクティブな研究 として行われた関東地区の多施設検討, 厚生省 研究班によるニューキノロン長期投与との比較 検討 ${ }^{10}$, さらに厚生省研究班のプロスペクティ ブ研究であるプラセボとの二重盲験比較試験 ${ }^{11}$ を通じて，EM療法の臨床的有効性は確固たる ものとなった. 図 2 に示す厚生省研究班登録患 者の予後調査 ${ }^{12)}$ (1995年) では, 初診が1970年 代の患者では, 5 年生存率 $63 \%, 7$ 年生存率 46 \%であり，EM療法報告以降の1985年以後の初 診患者では 5 年生存率 $91 \%, 7$ 年生存率でも約 90\%となっている. 今日では, DPBは早期に 診断し, 適切な治療を行えば, ほぼ治し得る疾 患になったと言って過言ではない。

図 3 は, 厚生省研究班によって策定された治 療ガイドライン ${ }^{13)}$ の骨子を示したものである. 第 1 選択薬としてはEM400〜600mgを, 症例 によっては，同じ14員環マクロライドであり， チトクロームP-450阻害による薬剤相互作用が 少ないクラリスロマイシン (CAM), ロキシス 


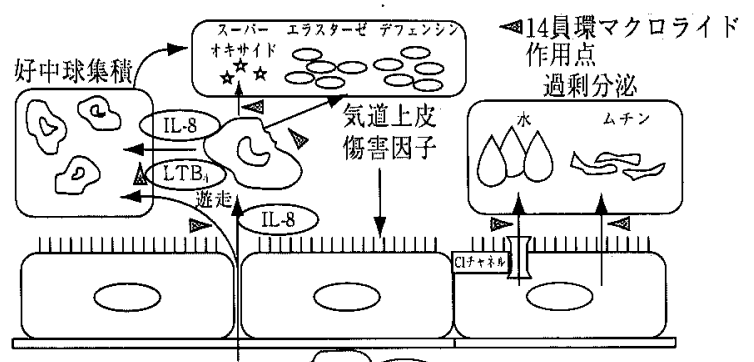

D好中球接着 P ( PCAM-D

図 4. 気道炎症病態と14貝環マクロライドの作用点

ロマイシン（RXM）が選択される。治療期間 としては, 初期例では 6 力月を経て正常化した もの，また進展例では 2 年を経て症状が安定し たものは終了するが，なお高度の呼吸障害を残 す患者にはさらに投与を継続する。

\section{EM療法の作用機序}

過去10年間のDPBをめぐる研究の焦点は, EM療法の普及と同時にその作用機序をいかに 考えるかにあった。その作用機序が本来の抗菌 作用でないことは，菌を排除しなくても疾患が 改善することや，感受性を持たない緑膿菌感染 症でも有効なこと等の臨床的観察に基づいてい る. EM療法の機序をめぐる研究の焦点は，主 としてDPBにおける気道の炎症病態との関連 におかれてきだ14.

図 4 は，現在までほぼ明らかにされた気道の 炎症病態とマクロライドの関わりを示したもの である：EMをはじめとするマクロライドは， ムチン ${ }^{15)}$ ささらにクロライドチャンネルを介し

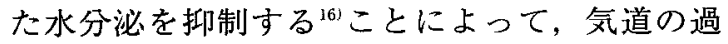
剩分泌を抑制する。また，好中球の血管内皮揖 よび気道上皮への接着抑制, 上皮細胞からのIL8 (interleukin-8) 遊離阻害 ${ }^{17-20)}$, さらに, 好中 球自身からのIL-8 やLTB-4（leukotriene B-4） などの遊離阻害などによって，好中球の炎症局 所への集積を抑制する. 加えて，好中球自体の 活性をも抑制することによって, 全体として活
性酸素, エラスターゼ, デフェンシンといった, 気道上皮に対する傷害因子を隇少させる。この ような作用は，慢性気道炎症の病態改善に直接 結びつく作用である。一方, リンパ球に対して はリンパ球の増殖・活性を䀼度依存的に抑制 し ${ }^{211}$, 単球一マクロファージ系の分化・增殖に 対しては濃度依存的に促進的に作用する ${ }^{22\}}$.

\section{4. 気道における感染と炎症}

この間の，いま一つのテーマは気道における 感染と炎症との関連であった。 EM療法以前の 治療では，気道感染をいかにコントロールする かに最大の力点が置かれた. インフルエンザ菌 を標的として $\beta$-ラクタム薬をはじめとする 様々な抗生物質の投与にもかかわらずその効果 は一時的であり, 多くは緑膿菌菌交代を生じて 疾患の悪化がもたらされた。一方, EM療法で は感染菌の除菌がなくても疾患は改善するが, 多数例でみるとインフルエンザ菌のみならず, 緑膿菌も減少する傾向が窥われ，正常細菌叢が 増加する.すなわち, 気道感染細菌叢の正常化 誘導である.

イギリスのCole. P教授が提唱する“慢性気道 感染の悪循環説” 23)では, 外因的・内因的に傷 害された気道粘膜に細菌が停滞し，それによる エラスターゼなどの気道上皮傷害因子と粘液の 過剩分泌によって持続感染状態が生じ, 疾患が さらに悪化する．DPBをはじめとする慢性気 道感染症におけるEM療法は, 図 5 のように, 気道の感染と炎症の悪循環において，気道上皮 傷害因子や過剩分泌を抑制し，炎症病態の改善 をはかることによって悪循環を断ち切り，結果 として感染そのものも良い方向に導いていると 考えられる。 


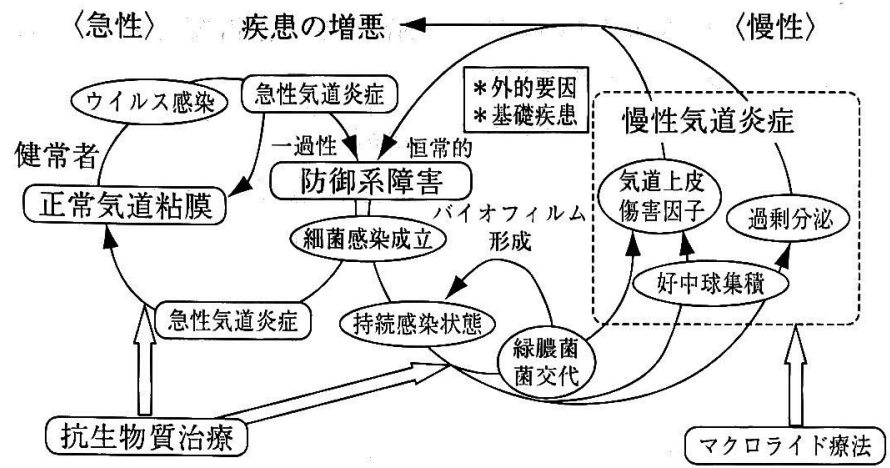

図 5. 気道に扔ける感染と炎症

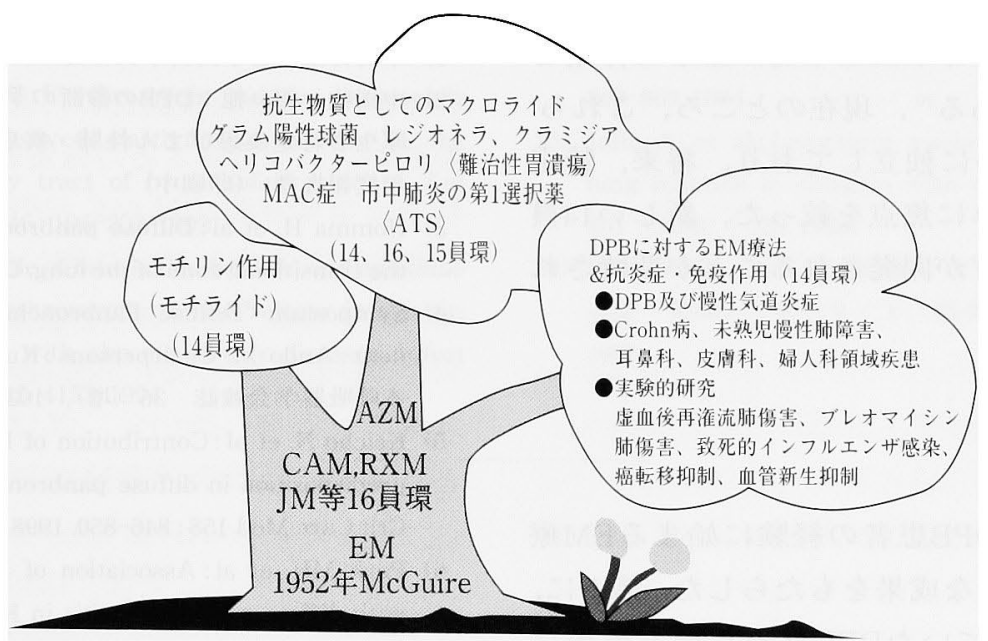

図 6. マクロライドの多様な作用

\section{5. マクロライド新作用をめぐる今後の 課題}

マクロライド薬は巨大なラクトン環を基本骨 格に持つ抗生物質であり，1952年にMcGiereに よって発見され，翌年にはわが国の臨床に用い られたEMの登場からすでに半世紀が経とうと している．抗生物質としてのマクロライドは14 員環（EM，CAM，RXM）から16員環（JMな ど)，そして15員環マクロライド (AZM) に至 る開発とともに, 感染症に対する重要な薬剂と して発展しつつある（図 6）. 一方，14員環マ
クロライドには腸管蠕動ホルモンでるモチリン 様作用（motilide）のあることが, 伊藤, 大村 ら ${ }^{24)}$ にってマクロライドの第 2 の作用として 明らかにされた。

$\mathrm{DPB}$ に対するEM療法は，今日，気管支拡張 症, 一部の気管支喘息, さらに耳鼻科領域にお ける慢性副鼻腔炎や淩出性中耳炎など，上，下 気道を通じた系統的気道粘膜の炎症性疾患に対 する14員環マクロライド療法として発展してい る.最近，わが国では現在なお健康保険末収載 である15員環マクロライドのアジスロマイシン (AZM) について, cystic fibrosisに効果のあっ たことが,イギリスのブロンプトン病院から 
Lancet誌に報告 ${ }^{25)}$ され，そのメカニズムはわが 国のDPBに対する14貝環マタロライドと同様 である可能性が論じられており，きわめて興味 媣い.

さらに現在，14員環マクロライドの全く新し い応用分野として，未熟児肺傷害やCrohn病な どに関する臨床応用の試みや，動物実験におけ る阻血後の再還流肺傷害, ブレオマイシン肺傷 害，さらにはインフルエンザウイルスによる肺 傷害，癌の転移や血管新生の抑制などに関する 研究が進められている。このようなEM療法の 研究を通じて明らかになった抗炎症・免疫作用 は14員環マクロライドにとって，第 3 の作用と いうべきものである ${ }^{26)}$. 現在のところ，これら 3 つの作用は互いに独立して扔り, 将来, 特定 の抗炎症作用のみに焦点を絞った，新しい14員 環系マクロライドが開発されることが期待され る.

\section{おわりに}

わずか 1 例のDPB患者の経験に始まるEM療 法は，以下のような成果をもたらした。第 1 に， 予後不良とされていたDPBを治し得る疾患に 変えたことである。第 2 に，慢性気道感染症に 招ける気道炎症病態の解明が進み, 感染と炎症 との一体的理解が進んだことである．第 3 に 14員環マクロライドの第 3 の作用というべき新 たな作用が明らかになり, 臨床応用の拡大と新 たな薬剤の創出への展望がもたらされたことで ある。そして現在の中心的な課題は，マクロラ イドの棈造と生物活性の相関に関する研究とと もに，細胞内のシグナル伝達や結合蛋白など， 細胞内分子レベルの作用機序の解明である、今 回，86年の本間教授による宿題報告から，13年 を経て再びDPBを取りあげる機会を与えてい ただいたが，疾患概念も治療法もわが国におい て確立し, 欧米に向かって発信しているこの研 究分野の成果を, 近い将来, さらに発展した段
階で再び報告できることを期待したい。

謝辞

本研究は，厚生省特定疾患びまん性肺疾患調 查研究班，「びまん性汎細気管支炎をめぐる研 究会」、「マクロライド新作用研究会」を中心と して，過去十数年に及ぶこの分野に扔ける多く の方々の研究によってなされたものである。こ の間の研究を支え，その推進にご協力下さった 各位に深謝する。

\section{文献}

1）本間日臣：日本内科学会雑誌 $75: 1347-1364,1986$.

2）中田紘一郎，他：DPBの診断の手引き(第 2 次改訂). 厚生省特定疾患びまん性肺疾患調查研究班, 平成10 年度報告揞 (印刷中)

3) Homma $\mathrm{H}$, et al: Diffuse panbronchiolitis : a disease of the transitional zone of the lung. Chest $83: 63-69,1983$.

4) Symposium "Diffuse Panbronchiolitis in Asia (President: Ando M. Chairpersons: Kudoh S. Zhu YJ)". 日 本呼吸器学会雑誌 36 (増), 103-108, 1998.

5) Keicho N, et al: Contribution of HLA genes to genetic predisposition in diffuse panbronchiolitis. Am J Respir Crit Care Med 158 : 846-850, 1998.

6) Park MH, et al: Association of HLA class I antigens with diffuse panbronchiolitis in Korean patients. Am J Respir Critic Care Med $159:$ 526 529, 1999.

7) 中田紘一郎, 他: 病理組織学的にびまん性沉細気管支 炎と診断された症例に関する検討，予後・治療．厚生 省特定疾患びまん性肺疾患調查研究班, 昭和 56 年度研 究報告春 $\mathrm{p} 25-28,1981$

8）谷本晋一，他：びまん性汎細気管支炎・自験例15剖検 例の検討. 内科 $41: 906-910,1978$.

9）工藤朔二，他：びまん性沉細気管支苂にたいするエリ スロマイシン少量長期投与の臨床効果 -4 年間の治療成 績。日胸疾会誌 $25: 632-642,1987$.

10）山本正彦，他：びまん性沉細気管支炏に対するエリス ロマイシン拉上びニューキノロン系薬剤の長期投与の 検討一全国票計の検討。日胸疾会誌 28:1305-1313, 1990.

11）山本正彦，他：DPBに対するエリスロマイシンの治療 効果一二重盲験による検討。厚生省特定疾患びまん性 肺疾患調查研究班報告書。p18-21, 1991.

12). Kudoh $\mathrm{S}$, et al: Improvement of survival in patients with diffuse panbronchiolitis. Am J Respir Critic Care 
Med 157 : 1829-32, 1998.

13）田口丵夫，他：DPBの治㙩ガイドライン，厚生省特定 疾思びまん性肺疾患調查研究班，平成10年度報告蓄 (印 刷中)

14) Kudoh $S$ : Erythromycin treatment in diffuse panbronchiolitis. Current Opinion in Pulmonary Medicine 4 : 116-121. 1998.

15) Goswami SK, et al. : Erythromycin inhibits respiratory glycoconjugate secretion from human airways in vitro. Am Rev Respir Dis 141 : 72-78. 1990.

16) Tamaoki J, et al: Erythromycin inhibits $\mathrm{Cl}$ secretion across canine tracheal epitherial cells. Eur Respir J 5 : 234-238. 1992.

17) Kadota $J$, et al : A mechanism of erythromycin treatment in patients with diffuse panbronchiolitis. Am Rev Respir Dis 147 : 153-159, 1993.

18) Ichikawa $Y$, et al: Erythromycin reduces neutrophils and neutrophil-derived elastlytic-like activity in the lower respiratory tract of bronchiolitis patients. Am Rev Respir Dis. 146 : 196-203, 1992.

19) Ooishi K, et al : Role of interleukin-8 (IL-8) and an inhibitory effect of erythromycin on IL-8 release in the airways of patients with chronic airway diseases. Infect Immunity $62: 4145^{-4152,} 1994$.
20) Takizawa $H$, et al: Erythromycin suppresses interleukin 6 expression by human bronchial epitherial cells : A potential mechanism of its anti-inflammatory action. Biochem Biophys Res Commun 210: 781-786, 1995.

21) Keicho N, et al : Antilymphocytic activity of erythromycin distinct from that of FK 506 or cyclosporin A. J Antibiotics 46: 1406-1413, 1993.

22) Keicho N, et al: Erythromycin promotes monocyte to macrophage differentiation. J Antibiotics 47:80-89. 1994.

23) Cole PC : A "vicious circle" hypothesis of the pathogenesis of bronchiectasis. Eur J Respir Dis 69 (suppl. 147) : 6-15, 1986.

24) Itoh $Z$, et al : Gastrointestinal motor-stimulating activity of macroride antibiotics and analysis of their side effects on the canine gut. Antimicrob Agents Chemothr 26 : 863-869, 1984.

25) Jaffe A, et al:Long-term azithromycin may improve lung function in children with cystic fibrosis. Lancet. 351 (9100) : 420, 1998.

26）清水喜八郎, 大村智 (監修), 工藤翔二（編集責任）： 炎症・兔疫とマクロライド。医薬ジャーナル社, 東京, 1996. 